\title{
周産期に発見される多囊腎の治療方針
}

大阪府立母子保健総合医療センター泌尿器科（主任：島田憲次）

東田章細川 尚三島田憲次

\section{MANAGEMENT OF MULTICYSTIC DYSPLASTIC KIDNEY DETECTED IN PERINATAL PERIODS}

\author{
Akira Tohda, Shozo Hosokawa and Kenji Shimada \\ Division of Urology, Osaka Medical Center and Research Institute of Maternal and Child Health \\ (Chief: Kenji Shimada)
}

We analized 17 cases of multicystic dysplastic kidney (MCDK) to document the natural history of MCDK and its management. One patient was nephrectomied for respiratory failure associated with MCDK. Follow-up studies of 14 kidneys revealed that 5 kidneys (36\%) did not change in size, 7 kidneys $(50 \%)$ decreased in size. Two kidneys (14\%) increased in size during the follow up periods and were nephrectomied. Hypertension and malignancy was not observed in our cases.

Evaluations for the contralateral kidney and urinary tract system were performed in 15 patients and $5(33 \%)$ revealed anormalies-two patients with VUR, 1 with PUJ stenosis, 1 with ureteral stricture and 1 with ectopic ureterocele.

In our hospital, the management for MCDK is conservative in most cases. Nephrectomy is indicated when there are complications resulting from the size of MCDK, or when the kidney continues to increase in size after the second year of life.

Key words: multicystic dysplastic kidney, management, natural history

\footnotetext{
要旨：当センターにおいて経験した片側の多囊腎17例につき，臨床経過の検討を行い，治療法の考察を 行った。 2 例は経過観察期間が短く，1例は多囊腎による圧迫のため生後すぐ腎摘除術を行った。残り 14 例中 5 例 (36\%) は多囊腎の大きさは不変で， 7 例（50\%）は縮小した。しかし， 2 例は，経過観察 中増大したため，腎摘除術を行った。高血圧，悪性腫瘍の発生は認めなかった。

対側の腎，尿路に対し検索を行ったのは15例で，ちち5例(33\%)に異常を認めた。 その内訳は, VUR

2 例，腎孟尿管移行部狭窄 1 例，中部尿管狭窄 1 例，異所性尿管瘤 1 例であった.

多囊腎の治療方針は，原則として経過観察でよいと考えられるが，周囲藏器への圧迫症状を呈する場 合や，2歳をすぎてもな増大傾向の見られる場合には，腎摘除術の適応となると考えられる．

キーワード：多囊腎，自然経過，治療方針
}

\section{緒 言}

多囊腎 (Mulicystic dysplastic kidney : MCDK) は, 画像診断法の発達により発見される頻度が増兄, 特に 近年では出生前に発見された症例の報告も多くなって いる．多囊腎の治療方針としては，以前は腎摘除術が 主として行われていたが，超音波断層法による長期 follow-upの結果, しばしば自然消失や縮小傾向がみ られるといら報告が増えている1) 5). そのため最近で は腫瘤の増大傾向や, 周囲臓器への圧迫症状がみられ ず，高血圧，悪性腫瘍の発生などの合併症も出現しな
い限り保存的に経過観察を行うとの意見が多(1) 5). そこで，今回，我々の経験した多囊腎17症例の臨床経 過を分析し，周産期に発見される多囊腎の治療方針に ついての検討を加えた。

\section{対 象}

1981年10月より，1991年12月の間に大阪府立母子保 健総合医療センターにおいて経験した多囊腎17症例を 対象とした。フォローアップ期間は出生直後に腎摘除 術を行ったものから109力月(平均23.5力月)であった。 性別では 17 例中男子が 6 例, 女子が 11 例であり, 女子 
Table 1 Clinical Features of Multicystic Dysplastic Kidney

\begin{tabular}{|c|c|c|c|c|c|c|c|}
\hline $\begin{array}{l}\text { Case } \\
\text { No. }\end{array}$ & $\begin{array}{c}\text { Sex/ } \\
\text { Affected Side }\end{array}$ & $\begin{array}{c}\text { Age/ } \\
\text { Presentation }\end{array}$ & $\begin{array}{l}\text { Change in } \\
\text { kidney size }\end{array}$ & Management & $\begin{array}{c}\text { Contralateral } \\
\text { kidney, urinary tract }\end{array}$ & $\begin{array}{c}\text { Associated } \\
\text { anomalies }\end{array}$ & $\begin{array}{c}\text { Follow-up } \\
\text { (mo) }\end{array}$ \\
\hline \multirow[t]{2}{*}{1} & $F / L$ & $5 \mathrm{M} / \mathrm{UTI}$ & N.C. & Conservative & Ureteral stenosis & none & 109 \\
\hline & & & & & Multiple cortical cysts & & \\
\hline 2 & $M / R$ & Prenate/USG & - & Nx. & VUR(grade I ) & none & $0^{\dagger}$ \\
\hline 3 & $M / R$ & Prenate/USG & Increased & $N x$ & Normal & none & $0^{\dagger}$ \\
\hline 4 & $F / L$ & Prenate/USG & Decreased & Conservative & Normal & none & 41 \\
\hline 5 & $F / L$ & Prenate/USG & Decreased & Conservative & Normal & True Intersex & 38 \\
\hline 6 & $M / R$ & Neonate/Mass & Decreased & Conservative & Normal & none & 37 \\
\hline 7 & $F / R$ & Prenate/USG & Increased & $\mathrm{Nx}$ & Normal & none & $28^{\dagger}$ \\
\hline 8 & $F / L$ & IM/ARF & N.C. & Conservative & Ectopic ureterocele & Rectovestibular fistula & 29 \\
\hline 9 & $F / R$ & Prenate/USG & Decreased & Conservative & Normal & none & 22 \\
\hline 10 & $F / L$ & Prenate/USG & N. C. & Conservative & Normal & none & 20 \\
\hline 11 & $F / R^{*}$ & Neonate/Mass & N. C. & Conservative & Normal & none & 17 \\
\hline \multirow[t]{2}{*}{12} & $F / R$ & Prenate/USG & Decreased & Conservative & Duplicated system & none & 16 \\
\hline & & & & & VUR(grade I ) into lower & & \\
\hline 13 & $M / L$ & Prenate/USG & Decreased & Conservative & Normal & none & 15 \\
\hline 14 & $F / R$ & Prenate/USG & Decreased & Conservative & - & none & 13 \\
\hline 15 & $F / L$ & Prenate/USG & N. C. & Conservative & - & none & 11 \\
\hline \multirow[t]{2}{*}{16} & $M / R$ & 4M/Mass & - & Conservative & PUJ stenosis & none & 2 \\
\hline & & & & & Multiple cortical cysts & & \\
\hline 17 & $M / R$ & Prenate/USG & - & Conservative & Normal & none & 2 \\
\hline
\end{tabular}

とされている症例には，1例の真性半陰陽を含んでい る.

\section{結＼cjkstart果}

1. 発見のきっかけ

Table 1 に, 当センターでの多囊腎17例の要約を示 す. 出生前に超音波断層法で発見された症例は12例， 出生後発見された症例は 5 例あり, 全例生後 5 力月立 でに発見された。出生後発見された症例のらち, 腹部 腫瘤により発見されたものは 3 例あり，その他，尿路 感染で発見されたのが 1 例, 急性腎不全で発見された のが 1 例ある。なお，初診時に腹部腫瘤を触知された のは，それが診断のきっかけとなった 3 例の他に，出 生前診断された症例も含めると, 計10例であった。

2. 臨床経過・治療法

（1）腎摘除術が加えられた症例

17例中, 経過観察期間が短く, 評価するのに不適当 と判断した症例が 2 例あり，これらの 2 例を除く 15 例 について臨床経過についての検討を行った. その結果, 1 例（症例 2) は巨大な多囊腎による圧迫のため呼吸 障害を呈したため, 出生直後に腎摘除術を行っている. 残る14症例について多囊腎の大きさの変化についての 評価が行われた。その結果， 2 例 (14\%) では腫瘤の 増大傾向がみられた（Fig. 1)。このうち症例 3 は, 出 生前から数回の超音波断層法で増大傾向が認められ，
Fig. 1 CT scan of case 7 .

A ; At the first day after birth. Right kidney revealed typical appearance of multicystic dysplastic kidney. B ; At the age of 2 years. Right multicystic dysplastic kidney gradually increased in size.
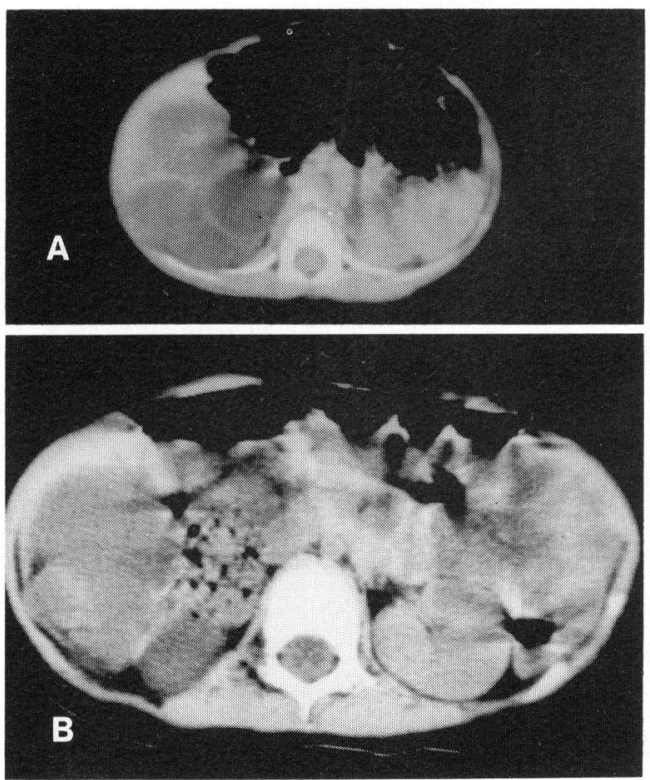
Fig. 2 CT scan of case 5 .

A ;At the first day after birth. Left kidney with some large Cysts. B ; At the age of 2 and half years. Left multicystic dysplastic kidney remarkablly decreased in size.
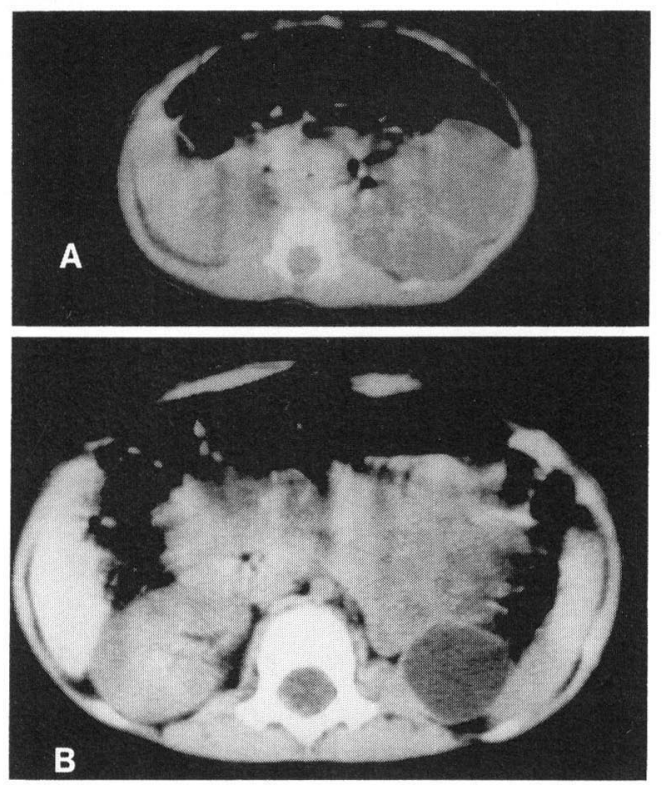

また多囊腎の圧迫による呼吸障害も伴っていたため生 後16日目に腎摘除術を施行した。症例 7 は, 腹部腫瘤 を触知する以外には無症状であったが, CT, 超音波断 層法で経過観察中に増大傾向を示し, 生後 2 年をすぎ ても増大していたため生後 2 年 4 力月で腎摘除術を 行った.

（2）保存的観察症例

多囊腎の絶対的な大きさが不変であったものは 5 例 (36\%)，縮小したものが 7 例 (50\%) あった (Fig. 2). これら12症例は, いずれも体幹に対しては相対的に縮 小しており, 超音波断層法, CTを定期的に施行され保 存的に経過観察されている. 尚, 我々の施設では現在 までのところ痕跡もなく全く自然消失した症例は認め ていない.

\section{3. 反対側腎尿路の異常}

一側の多囊腎においては, 反対側の腎尿路に奇形を ともなっていることが多い. 我々の症例においても腎 尿路精査が行われた15例の $5 ち 5$ 例 (33\%) に異常が 認められた。 その内訳は, VUR が 2 例に認められ, ら 1 例は重複腎而尿管の下腎に発生した VURであっ た。 その他, 中部尿管狭窄 1 例, 腎孟尿管移行部狭窄
症 1 例, そして異所性尿管瘤を 1 例認めた。 部尿管狭窄（症例 1 ）と, 腎盂尿管移行部狭窄（症例 16）の 2 例においては, 多囊腎とは反対側の腎藏にも multiple cortical cyst が認められた。 症例 1 は 9 歳 1 カ月で BUN $39.1 \mathrm{mg} / \mathrm{dl}$, 血清クレアチニン値 $1.4 \mathrm{mg} /$ dl であり, 症例 16 は 7 カ月で BUN $22.5 \mathrm{mg} / \mathrm{dl}$, 血清 クレアチニン値 $0.6 \mathrm{mg} / \mathrm{dl}$ と, ともに腎機能障害を示 している.

4. 腎尿路系以外の合併奇形

腎尿路系以外の合併奇形としては, 真性半陰陽が 1 例, 鎖肛 (直腸腟前庭瘻) が 1 例に認められた。高血 圧や，悪性腫瘍は我々の症例では, 現在のところ認め られていない。

\section{考察}

多囊腎は新生児の腹部腫瘤のうち最も高頻度にみら れるものの一つであり ${ }^{6) 7}$, 理学的に腫瘤が触知されな いとさにも超音波断層法で発見される症例が増えてい る. また, 近年の産科領域での超音波検査技術の進歩 により，当センターでも出生前に診断される症例が漸 増している (Fig. 3).

多囊腎の診断に扣いては，水腎症との鑑別がしばし ば問題になる、最も頻用される超音波検査に拈いては 腎の輪郭が分葉状であること，最大の囊胞が中央部に 位置しないこと, 囊胞間の交通がないこと, 正常の輝 度を持つ腎実質が認められないことなど注意深く観 察すれば多くは鑑別可能である ${ }^{8) 9}$. また, DMSA 腎シ

Fig. 3 Prenatal ultrasound scan of case 3 at the gastational age of 27 weeks showed multicystic dysplastic kidney.

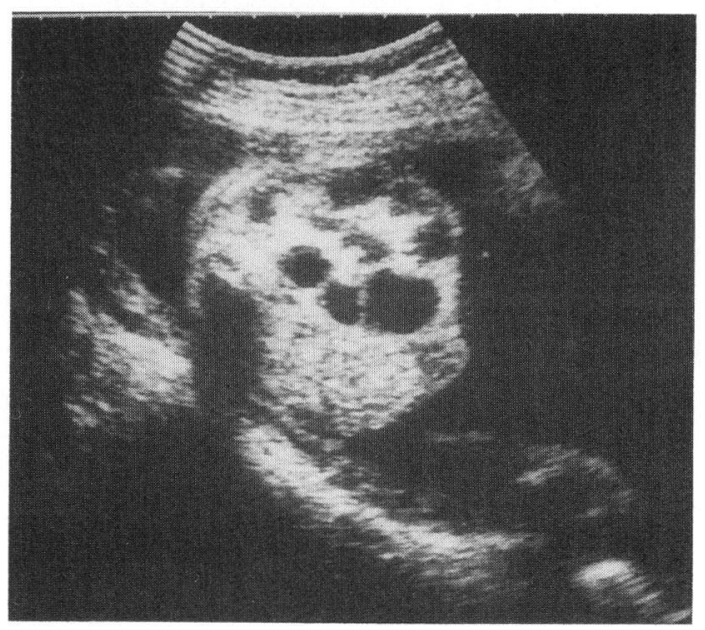


ンチグラフィーでアイソトープの集積を認めないこと や，排泄性腎孟造影（以下 IVP）で造影剤の排泄を認 めないことも診断のよりどころとなる。しかし，多囊 腎は“spectrum disease”であり，先天性水腎症との間 に境界領域と言兄るいわゆる hydronephrotic type の 多囊腎や，正常のネフロンの分化が多少なりとも認め られる型の多囊腎も存在している早10)。このような症 例に颃いては，CT や超音波断層法であたか子水腎症 のような像を呈したり，IVPにおいて造影剤の排泄を 認め, DMSA 腎シンチグラフィーでアイソトープも取 り込まれることがあり无, 水腎症との鑑別はきわめて 困難なこともある。このような場合には, 逆行性腎孟 造影により，上部尿管の閉塞を証明する必要がある。

また，一側性の多囊腎においては，反対側腎・尿路 に水腎症, VUR 等の異常を合併することが多く, 我々 の症例に沶いても，33\%の症例に対側腎尿路系の異常 を認めている。一側性多囊腎の症例は, 機能的に単腎 状態にあり, 反対側腎に合併病変があれば腎機能障害 をきたす可能性が高いため, 特にこのことを念頭にお いて, 超音波断.層法, 排尿時膀胱造影 (以下 VCG), IVPなどによる全尿路の精査が不可欠である。また， 前述のように対側腎に multiple cortical cyst を認め る症例を 2 例経験しており, これらの症例は多囊腎の 発生学上非常々興味深い症例である ${ }^{9}$.

多囊腎の治療方針としては，これまでは小児にみら れる大きな腹部腫瘤であること，画像診断で多囊腎と 確定する方法がなかったこと, そして合併症として悪 性化や高血圧の発生が報告されていた ${ }^{10)}$ 15) こと,など の理由で腎摘除術が行われていた。しかし, 我々の施 設では出生前に母性 (産科) 部門で発見される多囊腎 が多く, 以前より報告されていた本疾患の頻度よりは るかに高いことや, 今回の検討の結果及び, 文献的に も超音波検査による長期にわたる経過観察で, 自然消

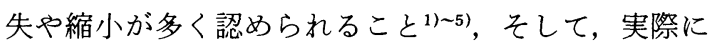
は, 悪性化や高血圧の確率は, 正常腎に比べて高くな (3)ことなどの理由から, 最近では周産期に括ける多 囊腎に対する治療方針としては，すぐに腎摘除術を行 らのではなく，まず保存的に経過観察を行うと言う意 見が多(1) 5).現在我々の行っている治療方針を以下 に示すと；

(1) 生直後に周囲臓器への圧迫症状を示さない症例 については，3 カ月毎に超音波断層法による検査を行 い, 異常を認める場合には, 適宜 CT, 腎シンチグラ フィ一等により精査を行う。経過観察中, 特に多囊腎
による合併症を示さず，多囊腎の大きさが不変あるい は縮小傾向を示す症例については, 高血圧, 腎機能の 推移および悪性化について特に注意を払いながら，保 存的に経過観察を行う.

（2) 大きな腹部腫瘤を呈し，超音波上，腎の増大がみ られる場合や，消化管や肺への圧迫症状を示す場合に は腎摘除術の適応となる。我々の経験では, 自然縮小 例は生後数力月までに縮小傾向がみられることが多 く, このため, 周囲臟器への圧迫症状を呈さない場合 には生後 2 年間は経過観察を行い, 2 年を過ぎてもな 譄大傾向の見られるものを腎摘除術の適応と考兄て いる。しかし, 周囲臟器への圧迫症状を呈する場合に は，早期に腎摘除術の適応となりらる。ょた，このよ らな症例については, 一時的に, 経皮的囊胞穿刺によ $\eta$ 全身状態の改善を待つ方法も有効との報告もあ $3^{16)}$. 経皮的囊胞穿刺した症例の, 囊胞の再増大等の長 期的な予後については，今のところ不明であるが，全 身状態不良な症例等には, 腎摘除術に変わる方法とし て注目される。その他, 高血圧や, 悪性腫崵の発生を 疑わせる所見を示す症例も腎摘除術の適応となり得る と考えられる。

\section{結 語}

当センターにおける多囊腎17例につき, その臨床経 過を分析し，治療方針につき検討を行った. 多囊腎は， 新生児期にみられる腹部腫瘤のらち, 最もよくみられ るものの一つであり, 近年では超音波検査の発達にと もない,より高頻度で発見されるようになってきてい る.このため, その診断および治療法の選択は今後よ り重要性が高くなる疾患であると考えられる。多囊腎 の治療は, 原則的に経過観察でよいが, 稀に増大傾向 を示したり, 周囲臟器への圧迫症状を呈することがあ り，そのような場合には腎摘除術を要することがある ため, 注意が必要である。

\section{文献}

1) Anvi, E.F., Thoua, Y., Lalmand, B., Didier, F., Droulle, P. and Schulman, C.C.: Multicystic dysplasitic kidney: Natural histry from in utero diagnosis and postnatal follow up. J. Urol., 138, 1420-1424, 1987.

2) Vinocur, L., Slovis, T.L., Perlmutter, A.D., Watts, F.B. and Chang, C.H.: Follow-up studies of multicystic dysplastic kidneys. Radiology, 167, 311-315, 1988.

3) Gordon, A.C., Thomas, D.F.M., Arthur, R.J. and Irving, H.C. ; Multicystic dysplastic kidney : Is 
nephrectomy still appropriate? J. Urol., 140, 1231-1234, 1988.

4) Pedicelli, G., Jequier, S., Bowen, A. and Boisvert, J.: Multicystic dysplastic kidneys : Spontaneous regression demonstrated with US. Radiology, 160, 23-26, 1986.

5) Bachmann, H., Winkielman, J. and Olbing, H. : Unilateral multicystic kidney dysplasia: Follow-up during the first two years of life. Contr. Nephrol., 67, 188-192, 1988.

6) Carey, P.O. and Howards, S.S.: Multicystic dysplastic kidney and diagnostic confusion on renal scan. J. Urol., 139, 83-84, 1988.

7) Kaplan, G.W. and Brock, W.A.: Abdominal masses. in : Clinical Pediatric Urology, 2nd ed., p. 57-75, Saunders Co., Philadelphia, 1985.

8) Stuck, K.J., Koff, S.A. and Silver, T.M. : Ultrasonic features of multicystic dysplastic kidney: Expanded diagnostic criteria. Radiology, 143, 217-221, 1982.

9) Sanders, R.C. and Hartman, D.S.: The sonographic distinction between neonatal multicystic kidney and hydronephrosis. Radiology, 151, 621-625, 1984.

10) Noe, H.N., Marshall, J.H. and Edwards, O.P.:
Nodular renal blastoma in the multicystic kidney. J. Urol., 142, 486-488, 1989.

11) Barrett, D.M. and Wineland, R.E.: Renal cell carcinoma in multisystic dysplastic kidney. Urology, 15, 152-154, 1980.

12) Birken, G., King, D., Vane, D. and Lloyd, T.: Renal cell carcinoma arising in a multicystic kidney. J. Pediatr. Surg., 20, 619-621, 1985.

13) Javadpour, N., Chenlouhy, E., Moncada, L., Rosenthal, I.M. and Bush, I.M.: Hypertension in a child caused by a multicystic kidney. J. Urol., 104, 918-925, 1970.

14) Chen, Y.H., Stapleton, F.B., Roy, S. and Noe, H. N.: Neonatal hypertension from a unilateral multicystic dysplastic kidney. J. Urol., 133, 664-665, 1985.

15) Hartman, G.E., Smolik, L.M. and Shochat, S.J. : The dilemma of multicystic dysplastic kidney. A.J.D.C., 140, 925-928, 1986.

16) Holloway, W.R. and Weinstein, S.H.: Percutaneous decompression: Treatment for respiratory destress secondary to multicystic dysplastic kidney. J. Urol., 144, 113-115, 1990. (1992年 4 月 8 日受理) 